\title{
Effect of Stocking Density on Growth and Survival of Gold-Spot Mullet, Liza parsia (Hamilton-Buchanan, 1822) Fry during Nursery Rearing in Cages
}

\author{
Sachin OnkarKhairnar ${ }^{1,2 *}$ H. S. Dhaker ${ }^{1}$, P. U. Kapse ${ }^{1}$, B. V. Solanki ${ }^{1}$, \\ P. E. Shingare ${ }^{1}$ and G. S. Ghode ${ }^{1}$ \\ ${ }^{1}$ College of Fisheries, Dr. Balasaheb Sawant Konkan Krishi Vidyapeeth, Ratnagiri, \\ Maharashtra, India \\ ${ }^{2}$ College of Fisheries, Guru Angad Dev Veterinary and Animal Sciences University, \\ Ludhiana, Punjab, India \\ *Corresponding author
}

\section{A B S T R A C T}

\section{Keywords}

Mullet, Liza parsia, Stocking density, Cages, Growth

\section{Article Info}

\section{Accepted:}

12 January 2021

Available Online:

10 February 2021
Liza parsia fry were reared at three different densities in the cages $\left(1 \times 1 \times 0.5 \mathrm{~m}^{-3}\right)$. The experiment was conducted to evaluate the effect of stocking density on growth, survival and biochemical composition during nursery rearing phase. Fry (mean length, $1.3 \mathrm{~cm}$ and mean weight, $0.08 \mathrm{~g}$ ) were stocked at the rate of 50,100 and 200 nos. $\mathrm{m}^{-3}$ for 30 days. The stocking density of 50 nos. $\mathrm{m}^{-3}$ was found to be better for rearing of fry of L. parsia in cages during nursery practices as it achieved the highest average length of $3.40 \mathrm{~cm}$, average weight 0.6125 , SGR of $6.01 \%$ day $^{-1}$ and survival of $80.57 \%$. There were marked differences between whole-body compositions among the fish reared at different densities. Stocking density showed inverse relationship with growth (length gain, weight gain and specific growth rate) and survival.

\section{Introduction}

In recent years, the Indian aquaculture industry has attempted to select new species of fish in order to diversify its production. In this context, the viability of aquaculture has been studied for some fish species like sea bass (Imelda et al., 2010), pangas (Singh and Lakra, 2012) and tilapia (Chakraborty and Banerjee, 2009). The potential success of a species is based on growth performance, on the availability of juveniles and market preference. The mullet species such as, Mugil cephalus, Liza parsia, L. tade, L. troshelli, and $L$. macrolepis are found along Ratnagiri coast, where $L$. parsia is a dominant species among the mullets (Barve, 1987). L. parsia is distributed in many countries, like Southeast Asia, Taiwan, the Mediterranean and Eastern European countries and in many parts of Central and South America and it products also contribute to valuable fishery economics in Japan and Australia (Nash and Shehadah, 1980). Aquaculture of mullets has great potential in brackish waters; its farming is still at infant stage in India compare to rest of 
world. Mullet culture is a good alternative to direct towards the intensification of production as it has gained the importance in several countries of South East Asia, because these fishes are considered of high quality priced. The mullet usually occur in coastal waters and estuaries throughout the tropical and subtropical belts of the world and sometimes even in temperate zones. They are known to ascend in schools to the shallow littoral areas and connected creeks, channels etc. with the high tide for feeding purposes and this characteristic habit is utilized while collecting them, using almost similar gears throughout the world. Active gears such as scoop nets, skimming nets and beach seines are commonly used to collect wild fry (Sadek and Mires, 2000; Liao, 1994).

In India the culture of mullets along with other compatible species of fish in brackish water impoundments is an age-old practice in West Bengal, Kerala and Andhra Pradesh $L$. Parsia fry are available in large quantities in the brackish waters of Ratnagiri coast, but their culture practice is still in infancy stage. The inclusion of a nursery phase in fish culture is necessary to obtain the hardy fingerlings. These fingerlings get acclimatized to the environment they are likely to encounter during the grow-out phase.

Cage culture is an advanced type of aquaculture. Its productivity is $10-20$ times higher than that of pond culture. It permits close observation of fish during the rearing stage, feeding and of general health (Feldlite and Milstein 1999). Stocking density is one of the most important variables in aquaculture because it directly influences survival, growth, behavior, health, water quality, feeding and production. In many studies, a high production of fish has been reported at an optimal stocking density, but decreases occur when stocking density exceeds this optimum (Rowland et al., 2006; Rahman et al., 2006). Under stocking results in failure to make the maximum possible utilization of the space and overstocking may result in stress that may reduce growth and feed utilization (Leatherland and Cho, 1985). Using appropriate stocking densities is the key for success in aquaculture management. The constant supply of fry of mullet is the most essential prerequisite for developing the culture. The wild collected fry of $L$. parsia directly stocked in culture pond leads to high mortality. Therefore, an attempt was made to rear the fry of $L$. parsia in cages.

\section{Materials and Methods}

\section{Experimental fish}

Fry of L. parsia were collected during low tide with the help of dragnet from the Kasarveli creek, situated at Sakhartar, Ratnagiri, Maharashtra State, Republic of India (16 $59^{\prime}$ $10^{\prime \prime} \mathrm{N}$ and $73^{\circ} 16^{\prime} 25^{\prime \prime} \mathrm{E}$ ). Collected fry was transported to the laboratory in plastic containers (20 litre capacity). Fry of L. parsia were identified by using the taxonomic key (Barve, 1987). The cages were installed in a brackish water pond located at College of Fisheries, Shirgaon, Ratnagiri campus. Area of the pond was $450 \mathrm{~m}^{2}(30 \mathrm{~m} \times 15 \mathrm{~m})$. During high tides, the depth of pond water was upto $110 \mathrm{~cm}$ while $90 \mathrm{~cm}$ at low tides. Rectangular shaped cages were constructed for the fry of $L$. parsia as described by Yu et al., (1979). Cage with dimension of $1 \mathrm{~m}(\mathrm{~L}) \times 1 \mathrm{~m}(\mathrm{~B}) \times 0.5 \mathrm{~m}$ (H) was with volume of $0.5 \mathrm{~m}^{3}$. Mosquito net cloth of polyamide (PA) with 24 mesh inch $^{-1}$ mesh size was used for preparation of cage bag. Two loops were attached at each corner of the cage bag to fix the bag with the bamboo. Loops were made from the extra mosquito net material; each loop was $6 \mathrm{~cm}$ in length. The top cover was connected with the cage bag for opening or closing the cage for feeding and maintenance. The cage was fixed by submersing $3 / 4^{\text {th }}$ part in water. 


\section{Experimental Design}

Fry with average initial length of $1.3 \pm 0.2$ $\mathrm{mm}$ and average initial weight of $0.08 \pm 0.03$ mg were stocked at the rate of 50, 100 and 200 nos. $\mathrm{m}^{-2}$ for 30 dayswith seven replicates each. Diet was given twice a day (9:00 h and 17:00 h) directly into cages. No special feeding area was provided in the cage.

\section{Diet Formulation}

Diet was formulated containing about 30\% protein by using different ingredients as given by Sawant et al., (2005). The ingredients and proximate composition of the test diets are given (Table 1). The moisture, crude protein, lipid and ash content in the test diets were analysed, according to standard procedures of Association of Official Analytical Chemist (AOAC, 1995).

\section{Water quality analysis}

Water parameters such as temperature, $\mathrm{pH}$, salinity, dissolved oxygen, carbon dioxide and alkalinity were analyzed every week outside and inside the cages according to standard methods APHA (2005).

\section{Statistical analysis}

All data on growth and survival were analysed by one-way ANOVA followed by Least Significant Difference (LSD) test. Differences were considered significant at $P$ $<0.05$ according to standard statistical methods by (Zar, 2004).

\section{Results and Discussion}

\section{Water quality}

The physio-chemical parameters of water during the experiment were maintained within the tolerance range for most teleost species used in aquaculture, as reported by several authors (Boyd, 1990; Boyd and Tucker, 1998). The water characteristics did not present any significant difference among fish densities or the two points monitored in reservoir. Water temperatures ranged from 28.4 to $30.2{ }^{\circ} \mathrm{C}$ (mean $29.3{ }^{\circ} \mathrm{C}$ ), $\mathrm{pH} 7.4$ to 8.0 (7.7), salinity 26 to $29 \mathrm{~g} / \mathrm{L}(27 \mathrm{mg} / \mathrm{L})$, DO 3.5 to $4.7 \mathrm{mg} / \mathrm{L}$ (4.1 mg/L), $\mathrm{CO}_{2} 8.2$ to $9.4 \mathrm{mg} / \mathrm{L}$ $(8.8 \mathrm{mg} / \mathrm{L})$, and alkalinity 120 to $138 \mathrm{mg} / \mathrm{L}$ (127.5 mg/L).

\section{Fish survival}

Survival was significantly affected by stocking density $(\mathrm{P}<0.05)$. Mean survival rates were $80.57,72.42 \%$ and $60.14 \%$ in cages at 50, 100 and $200 \mathrm{fish} / \mathrm{m}^{3}$, respectively (Table 2). Survival was similar to that observed for gold spotted mullet reared under laboratory conditions according to Sawant (2002). Similarly, Chavan, (2002) many studies have found significant effects of density on survival. Diseases are a potential problem in the cage culture of fish. Apparently, the mortalities of L.parsia fry were not associated to diseases. Mortality was observed only at the beginning of the experiment in low and intermediate stocking densities as compare to high stocking density $200 \mathrm{fish} / \mathrm{m}^{3}$. This was probably the result of low acceptance of some fish to the formulated diet and high stocking density, since dead fish presented clear signals of emaciation. Therefore, mortality rates were related to stocking density as might be expected. Similarly, mortality of silver perch, Bidyanus bidyanus, reared in the cages was dependent upon the stocking density Rowland et al., (2006).

\section{Fish growth}

Final weight was significantly $(\mathrm{P}<0.05)$ influenced by stocking densities (Table 2). Various studies with L.parsia fry report 
similar results according to the type of culture. El-Sayed (2002) observed increase in stocking density resulted in significantly poor growth rates. Similar observations were also made during the present investigation. Weight gain of $508.46 \%$ for fry of L. parsia reared at 50 numbers $\mathrm{m}^{-2}$ was significantly higher
$(P<0.05)$ than other stocking densities for 30 days. Prasadam et al., (1988) observed maximum weight gain for fingerlings of $M$. cephalus and L. macrolepis at 40000 number $\mathrm{ha}^{-1}$ in cages for 6 months and showed inverse relationship with the stocking density which was similar to the present study.

Table.1 Proportion of ingredients and proximate composition of diet used in rearing of $L$. parsia in cages

\begin{tabular}{|l|c|}
\hline Proportion of ingredients & \\
\hline Ingredients & Quantity $(\%)$ \\
\hline Wheat flour & 12.18 \\
\hline Rice bran & 12.18 \\
\hline Whole poultry egg & 37.82 \\
\hline Mustard Oil Cake & 37.82 \\
\hline Proximate composition & \\
\hline Crude Protein $(\%)$ & 31.57 \\
\hline Crude Fat $(\%)$ & 9.61 \\
\hline Moisture & $\mathbf{8 . 9 1}$ \\
\hline Ash $(\%)$ & 5.82 \\
\hline Carbohydrate* $(\%)$ & 44.09 \\
\hline Gross energy $\left(\mathrm{kcal} \mathrm{g}^{-1}\right) * *$ & 450.43 \\
\hline
\end{tabular}

$*$ Carbohydrate $(\%)=(100 \%)-[(\%$ Protein $)+(\%$ Fat $)+(\%$ Moisture $)+(\%$ Ash $)] \ldots$ (Woods and Aurand, 1977) $* *$ Gross energy $\left(\mathrm{Kcal} \mathrm{g}^{-1}\right)=($ Crude protein $\mathrm{x} 5.65)+($ Crude fat $\mathrm{x} 9.5)+($ Carbohydrate $\mathrm{x} 4.1) \ldots(\mathrm{El}-$ Sayed, 2002).

Table.2 Effects of stocking densities on growth and survival of L. parsia fry in cages

\begin{tabular}{|c|c|c|c|c|c|c|}
\hline $\begin{array}{l}\text { Stocking } \\
\text { Density } \\
\left(\text { fry } \mathbf{~ m}^{-2}\right)\end{array}$ & $\begin{array}{c}\text { Final } \\
\text { length } \\
\text { (cm) }\end{array}$ & $\begin{array}{c}\text { Length gain } \\
\text { (g) }\end{array}$ & $\begin{array}{c}\text { Final } \\
\text { weight } \\
\text { (g) }\end{array}$ & $\begin{array}{c}\text { Weight } \\
\text { gain } \\
\text { (g) }\end{array}$ & SGR* & $\begin{array}{c}\text { Survival } \\
(\%)\end{array}$ \\
\hline 50 & 3.40 & 2.12 & 0.6125 & 0.5325 & 6.0101 & 80.57 \\
\hline 100 & 2.75 & 1.43 & 0.5042 & 0.4242 & 5.4085 & 72.42 \\
\hline 200 & 2.46 & 1.16 & 0.4055 & 0.325 & 4.7742 & 60.14 \\
\hline
\end{tabular}

Table.3 Water quality parameters during the experiment

\begin{tabular}{|c|c|c|c|c|c|c|}
\hline Weeks & $\begin{array}{c}\text { Temperature } \\
(\mathbf{C})\end{array}$ & $\mathbf{p H}$ & $\begin{array}{c}\text { Salinity } \\
\left(\mathbf{g ~ L}^{-\mathbf{1}}\right)\end{array}$ & $\begin{array}{c}\text { DO } \\
\left(\mathbf{m g ~ L}^{\mathbf{- 1}}\right)\end{array}$ & $\begin{array}{c}\mathbf{C O}_{\mathbf{2}} \\
\left(\mathbf{m g ~ L}^{\mathbf{- 1}}\right)\end{array}$ & $\begin{array}{c}\text { Alkalinity } \\
\left(\mathbf{m g ~ L}^{-\mathbf{1}}\right)\end{array}$ \\
\hline $\mathbf{1}$ & 29.6 & 7.4 & 26 & 4.0 & 9.4 & $\mathbf{1 3 5}$ \\
\hline $\mathbf{2}$ & 30.2 & 8.0 & 27 & 3.5 & 8.6 & $\mathbf{1 2 0}$ \\
\hline $\mathbf{3}$ & 28.4 & 7.5 & 27 & 4.4 & 8.4 & $\mathbf{1 3 8}$ \\
\hline $\mathbf{4}$ & 29.8 & 7.6 & 29 & 3.8 & 8.2 & $\mathbf{1 3 2}$ \\
\hline
\end{tabular}


Specific growth rate was significantly affected by stocking densities $(\mathrm{P}<0.05)$. SGR of $6.01 \%$ was recorded at 50 fry $\mathrm{m}^{-2}$ for 30 days which was reasonably higher than other stocking densities. Sawant (2002) reported specific growth rate of $3.45 \%$ for $L$. parsia for rearing period of 90 days. Narvekar \& Chavan (2002) recorded specific growth rate of $3.55 \%$ and $3.52 \%$ respectively for L. parsia for rearing period of 90 days. The higher specific growth rate for fry of $L$. parsia in present study as compared to above referred studies may be due to rearing in the cages and phase of rearing. According to Rahman et al., (2006) reported that specific growth rate decreased with increase in stocking density. Similar trend was observed during the present study.

Better growth performance is always the aim of aquaculture farmers. According to the result of present study, stocking density of L.parsia fry @ 50 nos. $\mathrm{m}^{-3}$ can be reared in the cage $\left(1 \times 1 \times 0.5 \mathrm{~m}^{-3}\right)$. Thus, commercial mullet farmers could obtain the fastest growth rate and improved survival asit permits close observation of fish during the nursery rearing stage, feeding and of general health.This information can be utilized by farmers for various freshwater as well as brackishwater species to maximize commercial productivity.

\section{References}

APHA (2005) Standard Methods for the examination of water and waste water, $21^{\text {st }}$ edition, American Public Health Association, Washington, USA, 1368p.

AOAC (1975) Official Methods of Analysis, $12^{\text {th }}$ edition Association of Official Analytical Chemist, Washington D.C. 1094p.

Barve, S.K.(1987) Systematic and biological studies on the mullets (Pisces: Mugilidae) off Ratnagiri. M.Sc. Thesis, Konkan Krishi Vidyapeeth, Dapoli,
India.

Boyd, C.E. (1990) Water Quality in Ponds for Aquaculture. Auburn University, Alabama. 482p.

Boyd, C.E. and Tucker, C.S. (1998) Water Quality and Pond Soil Analysis for Aquaculture. Alabama Agricultural Experiment Station, Alabama, USA. $700 \mathrm{p}$.

Chakraborty, S. B. and Banerjee S. (2009) Culture of Monosex Nile Tilapia under Different Traditional and NonTraditional Methods in India, World Journal of Fish and Marine Sciences 1 (3): 212-217.

Chavan, S.L. (2002) Supplementation of Biotin in practical diet of Liza parsia fry. M.F.Sc. Thesis, Konkan Krishi Vidyapeeth, Dapoli, India.

El-Sayed, A.M. (2002) Effect of stocking density and feeding levels on growth and feed efficiency of Nile tilapia fry. Aquaculture Research33: 621-626.

Feldlite, M. and Milstein. A. (1999) Effect of density on survival and growth of cyprinid fish fry. AquacultureInterternational7:399-411.

Imelda, S., Shoji J., Boby I., Sydarao, G., Sobhana, K. S., Prema, D. and Varghese, M. (2010) A pilot study on culture of Asian seabass, Latescalcarifer (Bloch) in open sea cage at Munambam, Cochin coast, India. Indian Journal of Fisheries, 57(3):29-33.

Leatherland, J.F. and Cho, C.Y. (1985) Effect of rearing density on thyroid and interrenal, gland activity and plasma hepatic metabolite levels in Salmo gardineri. Journal of Fish Biology27: 583-592.

Nash, C.E. and Shehadeh, Z.H. (1980). Review of breeding and propagation techniques for grey mullet, Mugilcephalus L. ICLARM Studies and Reviews 3, 87 p. International Center' for Living Aquatic Resources 
Management, Manila, Philippines.

Prasadam R.D. and Kadir P.M.A. (1988) Experimental pen and cage culture of grey mullets in the Pulicate Lake. In: (Ed. M. Mohan Joseph) The First Indian Fisheries Forum, Proceedings. Asian Fisheries Society, Indian Branch, Mangalore: 143-145.

Rahman, M.M., Islam, M.S., Halder, G.C. and Tanaka, M. (2006) Cage culture of sutchi catfish, Pangasius sutchi: effects of stocking density on growth, survival, yield and farm profitability. Aquaculture Research37: 33-39.

Rowland, S.J., Mifsud, C., Nixon, M. and Boyd, P. (2006) Effects of stocking density on the performance of the Australian freshwater silver perch (Bidyanus bidyanus) in cages. Aquaculture 253: 301-308.

Sadek, S. and Mires, D. (2000) Capture of wild finfish Fry in Mediterranean coastal areas and possible impact on aquaculture development and marine genetic resources. The Israeli Journal of Aquaculture - Bamidgeh, 52(2) 7788.

Sawant, G.P., Singh H., Sawant, N.H. and Shirdhankar, M.M. (2005) Effects of different oil cakes on the growth and survival of Liza parsia. Fishery Technology42: 37-40.

Singh, A. K. and Lakra, W.S. 2012. Culture of Pangasianodon hypophthalmus into India: Impacts and Present Scenario. Pakistan Journal of Biological Sciences, 15: 19-26.

$\mathrm{Yu}$ O.K., Vizcarra A.T. and Siltoy H.S. (1979) Development of circular floating cages for milkfish broodstock at the SEAFDEC Aquaculture Department. In: Proceedings of the IRDC/SEAFDEC International Workshop on Pen and Cage Culture of Fish, SEAFDEC Aquaculture Department, Tigbaun, Iliolo, Philippines. pp. 107-117.

Zar, J.H.(2004)Biostatistical Analysis, fourth edition, Tan prints (I) Pvt. Ltd., Delhi, India. 663p.

\section{How to cite this article:}

Sachin OnkarKhairnar' H. S. Dhaker, P. U. Kapse, B. V. Solanki, P. E. Shingare and Ghode, G. S. 2021. Effect of Stocking Density on Growth and Survival of Gold-spot Mullet, Liza parsia (Hamilton-Buchanan, 1822) Fry during Nursery Rearing in Cages. Int.J.Curr.Microbiol.App.Sci. 10(02): 156-161. doi: https://doi.org/10.20546/ijcmas.2021.1002.020 